\title{
Natural and Human-Transformed Vegetation and Landscape Reflected by Modern Pollen Data in the Boreonemoral Zone of Northeastern Europe
}

\author{
Normunds Stivrins 1,2,3,*俄, Agrita Briede ${ }^{1}$, Dace Steinberga ${ }^{4}$, Nauris Jasiunas ${ }^{1}$, Jurijs Jeskins ${ }^{4}$, \\ Laimdota Kalnina ${ }^{1,3}$, Alekss Maksims ${ }^{4}$, Zigmars Rendenieks ${ }^{1}$ (D) and Liva Trasune ${ }^{1,5}$ \\ 1 Department of Geography, University of Latvia, Jelgavas iela 1, LV-1004 Riga, Latvia; \\ agrita.briede@lu.lv (A.B.); nauris.jasiunas@lu.lv (N.J.); laimdota.kalnina@lu.lv (L.K.); \\ zigmars.rendenieks@lu.lv (Z.R.); liva.trasune@lu.lv (L.T.) \\ 2 Department of Geology, Tallinn University of Technology, Ehitajate tee 5, EE-19086 Tallinn, Estonia \\ 3 Lake and Peatland Research Centre, LV-4063 Aloja, Latvia \\ 4 Department of Geology, University of Latvia, Jelgavas iela 1, LV-1004 Riga, Latvia; \\ dace.steinberga@lu.lv (D.S.); jurijs.jeskins@lu.lv (J.J.); alekss.maksims@lu.lv (A.M.) \\ 5 Department of Geosciences and Geography, University of Helsinki, P.O. Box 64, FI-00014 Helsinki, Finland \\ * Correspondence: normunds.stivrins@lu.lv
}

Citation: Stivrins, N.; Briede, A.;

Steinberga, D.; Jasiunas, N.; Jeskins, J.;

Kalnina, L.; Maksims, A.; Rendenieks,

Z.; Trasune, L. Natural and

Human-Transformed Vegetation and

Landscape Reflected by Modern

Pollen Data in the Boreonemoral

Zone of Northeastern Europe. Forests

2021, 12, 1166. https://doi.org/

10.3390/f12091166

Received: 20 July 2021

Accepted: 25 August 2021

Published: 28 August 2021

Publisher's Note: MDPI stays neutral with regard to jurisdictional claims in published maps and institutional affiliations.

Copyright: (c) 2021 by the authors. Licensee MDPI, Basel, Switzerland. This article is an open access article distributed under the terms and conditions of the Creative Commons Attribution (CC BY) license (https:// creativecommons.org/licenses/by/ $4.0 /)$.

\begin{abstract}
Modern pollen composition obtained from waterbody surface sediment represents surrounding vegetation and landscape features. A lack of detailed information on modern pollen from Latvia potentially limits the strength of various pollen-based reconstructions (vegetation composition, climate, landscape, human impact) for this territory. The aim of this study is to compare how modern pollen from natural and human-made waterbodies reflects the actual vegetation composition and landscape characteristics. Modern pollen analyses from surface sediment samples of 36 waterbodies from Latvia alongside oceanic-continental, lowland-upland, urban-rural and forested-agricultural gradients have been studied. In addition, we considered the dominant Quaternary sediment, soil type and land use around the studied waterbodies in buffer zones with widths of one and four $\mathrm{km}$. The information on climate for the last 30 years from the closest meteorological station for each study site was obtained. Data were analyzed using Pearson correlation and principal component analysis. Results show that relative pollen values from surface sediment of waterbodies reflect dominant vegetation type and land use. Modern forest biomass had a positive correlation with pollen accumulation rate, indicating the potential use of pollen-based forest biomass reconstructions for the boreonemoral zone after additional research and calibration.
\end{abstract}

Keywords: forest; agriculture; natural; urban; lake; pond; Latvia; CORINE

\section{Introduction}

Pollen is one of the most abundant microfossils (sub-fossils) preserved in sediment archives, whose sedimentary assemblages are related to regional and local vegetation [1,2]. Whilst fossil pollen can be found in lake sediments extending back for thousands of years, modern pollen surface samples are a component of that fossil record found in the last decades. Modern pollen samples from lake surface sediment reflect differences in vegetation in a similar way to moss pollsters, pollen traps, and might be combined for vegetation or climate calibration purposes [3].

In a time when the modeling approach is significantly expanding, the production of raw data is less attractive to new and established researchers because it is time- and labor-consuming. Nevertheless, modeling of climate, environmental change, forest biomass reconstructions or distribution of biota, vegetation functionality and phylogenetic diversity require input data and validation [4-9]. Although limited in spatial coverage and affected by uncertainties [10], proxy records are used in model-data comparisons and quantitative 
syntheses [11,12]. For example, climate models are commonly validated against proxybased (e.g., pollen) reconstructions. These models should be able to reproduce past climate and vegetation change to be useful in future projections (e.g., [13]). To improve our ability to reconstruct environments and climate, modern proxy calibration studies along climatic and ecological gradients are needed. Modern pollen surface samples currently have a low spatial resolution in Latvia, i.e., 10 samples [14], therefore lacking the full potential estimated current, past and possible future natural and anthropogenic processes.

The aim of this study is to compare how modern pollen from natural and humanmade waterbodies in Latvia, northeastern Europe reflect actual vegetation composition and landscape characteristics. For the first time in Latvia, modern pollen from 36 waterbody sediment surfaces were analyzed and compared with local vegetation composition, biomass, dominant Quaternary sediment type and climate.

\section{Materials and Methods}

\subsection{Study Sites}

The study sites are situated $55-58^{\circ} \mathrm{N}$ and $20-28^{\circ} \mathrm{E}$ in Latvia, northeastern Europe (Figure 1; Table 2) in the hemiboreal forest zone, which is characterized by a mixture of coniferous and deciduous tree species, such as the Norway spruce (Picea abies), Scots pine (Pinus sylvestris), birch (Betula spp.), alder (Alnus glutinosa, Alnus incana), wych elm (Ulmus glabra), European ash (Fraxinus excelsior), small-lived lime (Tilia cordata) and pedunculate oak (Quercus robur).

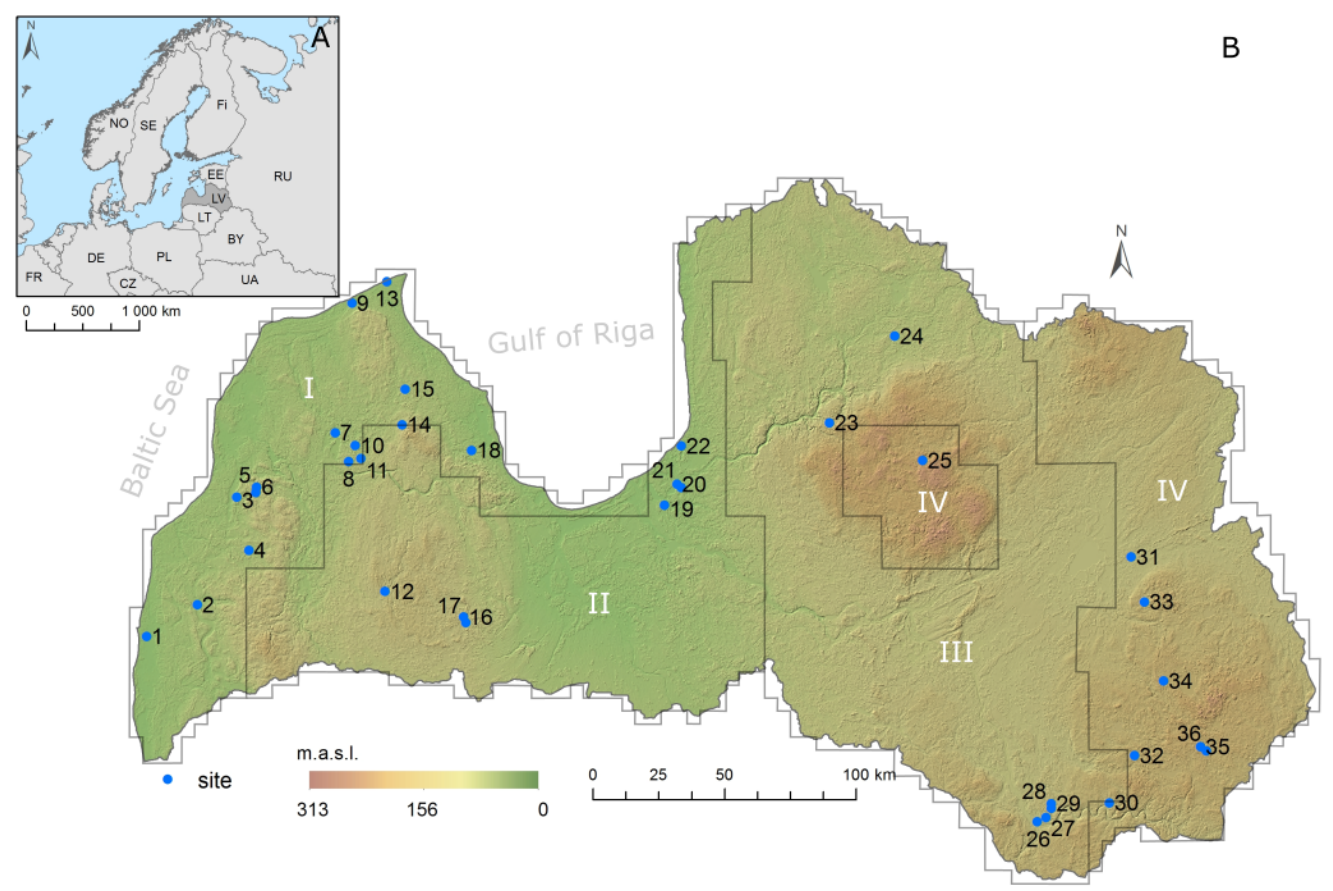

Figure 1. Study area in Europe (A) and the location of waterbodies in Latvia used in current article (B): 1-Lake Liepājas, 2-Lake Durbes, 3-Dam Alsungas, 4-Lake Kikuru, 5-Lake Pinku, 6Pond Cūku, 7-Lake Usmas, 8-Lake Sūnezers, 9-Lake Lielais Pēterezers, 10-Lake Rūmikis, 11-Lake Vēžezers, 12-Lake Saldus, 13-Dam Vaides, 14-Lake Talsu, 15-Lake Sasmakas, 16Lake Sesavas, 17-Lake Lielais Vipēdes, 18-Lake Vaskaris, 19-Lake Velnezers, 20-Lake Sekšu, 21-Lake Mazais Baltezers, 22-Lake Lilastes, 23-Lake Āraišu, 24-Lake Trikātas, 25-Lake Bricu, 26-Pond Esplanādes, 27-Lake Gubiščes, 28-Lake Mazais Stropu, 29-Lake Lielais Stropu, 30Lake Gluhoje, 31-Lake Lielais Svētinu, 32-Lake Čertoks, 33-Lake Puderovas, 34-Lake Zosnas, 35-Lake Dagdas, 36-Pond Dagdas. Roman numbers indicate continentality index zones: I—weak, II-moderate, III-average, IV—strong. 
Table 1. Study sites and related information.

\begin{tabular}{|c|c|c|c|c|c|c|c|}
\hline No & Site Name & $\begin{array}{c}\text { Coordinates, } \\
\mathrm{N}, \mathrm{E}\end{array}$ & $\begin{array}{l}\text { Elevation, } \\
\text { m a.s.l. }\end{array}$ & Size, ha & $\begin{array}{l}\text { Water Depth, } \\
\text { max/mean, m }\end{array}$ & $\begin{array}{c}\text { Hydrology, Through- } \\
\text { flow/Inflow/Outflow/None }\end{array}$ & Reference \\
\hline 1 & Lake Liepājas & $\begin{array}{c}56^{\circ} 29^{\prime} 21.35^{\prime \prime} \\
21^{\circ} 2^{\prime} 58.65^{\prime \prime}\end{array}$ & 0.2 & 3715 & $2.8 / 2$ & throughflow & This study \\
\hline 2 & Lake Durbes & $\begin{array}{c}56^{\circ} 36^{\prime} 40.91^{\prime \prime} \\
21^{\circ} 21^{\prime} 1.05^{\prime \prime}\end{array}$ & 23 & 670 & $8.1 / 3.9$ & throughflow & This study \\
\hline 3 & Dam Alsungas & $\begin{array}{l}56^{\circ} 58^{\prime} 50.82^{\prime \prime} \\
21^{\circ} 34^{\prime} 19.07^{\prime \prime}\end{array}$ & 22 & 7.8 & $2.5 / 2$ & throughflow & This study \\
\hline 4 & Lake Kikuru & $\begin{array}{c}56^{\circ} 48^{\prime} 4.45^{\prime \prime} \\
21^{\circ} 39^{\prime} 38.57^{\prime \prime}\end{array}$ & 38.7 & 21.6 & $4.3 / 1.9$ & throughflow & [14] \\
\hline 5 & Lake Pinku & $\begin{array}{l}56^{\circ} 59^{\prime} 56.82^{\prime \prime} \\
21^{\circ} 41^{\prime} 17.77^{\prime \prime}\end{array}$ & 54 & 29 & $20 / 5$ & throughflow & This study \\
\hline 6 & Pond Cūku & $\begin{array}{c}57^{\circ} 1^{\prime} 2.44^{\prime \prime} \\
21^{\circ} 41^{\prime} 36.71^{\prime \prime}\end{array}$ & 42.5 & 1.2 & $1.2 / 0.6$ & throughflow & This study \\
\hline 7 & Lake Usmas & $\begin{array}{l}57^{\circ} 11^{\prime} 52.23^{\prime \prime} \\
22^{\circ} 7^{\prime} 50.94^{\prime \prime}\end{array}$ & 21 & 3469.2 & $17 / 5.4$ & throughflow & This study \\
\hline 8 & Lake Sūnezers & $\begin{array}{l}57^{\circ} 6^{\prime} 46.93^{\prime \prime} \\
22^{\circ} 15^{\prime} 55.74^{\prime \prime}\end{array}$ & 48.8 & 1.4 & $3.7 / 1.5$ & none & [14] \\
\hline 9 & $\begin{array}{l}\text { Lake Lielais } \\
\text { Pēterezers }\end{array}$ & $\begin{array}{l}57^{\circ} 39^{\prime} 13.93^{\prime \prime} \\
22^{\circ} 15^{\prime} 39.45^{\prime \prime}\end{array}$ & 9 & 2.9 & $3.1 / 2$ & none & This study \\
\hline 10 & Lake Rūmikis & $\begin{array}{l}57^{\circ} 10^{\prime} 8.37^{\prime \prime} \\
22^{\circ} 18^{\prime} 12.79^{\prime \prime}\end{array}$ & 40 & 1.5 & $4.3 / 1.5$ & outflow & [14] \\
\hline 11 & Lake Vēžezers & $\begin{array}{l}57^{\circ} 7^{\prime} 28.75^{\prime \prime} \\
22^{\circ} 20^{\prime} 26.79^{\prime \prime}\end{array}$ & 50 & 7 & $1.7 / 1.4$ & outflow & [14] \\
\hline 12 & Lake Saldus & $\begin{array}{l}56^{\circ} 40^{\prime} 26.92^{\prime \prime} \\
22^{\circ} 30^{\prime} 39.42^{\prime \prime}\end{array}$ & 89 & 22 & $4.6 / 2.5$ & throughflow & This study \\
\hline 13 & Dam Vaides & $\begin{array}{l}57^{\circ} 43^{\prime} 42.71^{\prime \prime} \\
22^{\circ} 28^{\prime} 35.54^{\prime \prime}\end{array}$ & 6.2 & 5.4 & $1.7 / 1$ & throughflow & This study \\
\hline 14 & Lake Talsu & $\begin{array}{l}57^{\circ} 14^{\prime} 33.58^{\prime \prime} \\
22^{\circ} 35^{\prime} 47.27^{\prime \prime}\end{array}$ & 64 & 3.6 & $16.5 / 11.6$ & throughflow & This study \\
\hline 15 & Lake Sasmakas & $\begin{array}{l}57^{\circ} 21^{\prime} 55.39^{\prime \prime} \\
22^{\circ} 36^{\prime} 36.21^{\prime \prime}\end{array}$ & 36 & 252 & $7.4 / 3.8$ & throughflow & This study \\
\hline 16 & $\begin{array}{l}\text { Lake Sesavas } \\
\text { lake }\end{array}$ & $\begin{array}{c}56^{\circ} 34^{\prime} 18.38^{\prime \prime} \\
23^{\circ} 1^{\prime} 1.67^{\prime \prime}\end{array}$ & 36.6 & 17 & $4.2 / 2.7$ & throughflow & This study \\
\hline 17 & Lielais Vipēdes & $\begin{array}{c}56^{\circ} 35^{\prime} 28.07^{\prime \prime} \\
23^{\circ} 0^{\prime} 2.33^{\prime \prime}\end{array}$ & 96 & 20.1 & $3.3 / 2.3$ & throughflow & This study \\
\hline 18 & Lake Vaskaris & $\begin{array}{l}57^{\circ} 9^{\prime} 35.68^{\prime \prime} \\
23^{\circ} 2^{\prime} 11.71^{\prime \prime}\end{array}$ & 15.4 & 22.1 & $2.8 / 1$ & throughflow & [14] \\
\hline 19 & Lake Velnezers & $\begin{array}{l}56^{\circ} 58^{\prime} 34.47^{\prime \prime} \\
24^{\circ} 14^{\prime} 48.84^{\prime \prime}\end{array}$ & 4.5 & 3.5 & $6 / 3.5$ & none & This study \\
\hline 20 & Lake Sekšu & $\begin{array}{l}57^{\circ} 2^{\prime} 12.33^{\prime \prime} \\
24^{\circ} 21^{\prime} 8.38^{\prime \prime}\end{array}$ & 5 & 11.7 & $6 / 2.5$ & inflow & [14] \\
\hline 21 & $\begin{array}{l}\text { Lake Mazais } \\
\text { Baltezers }\end{array}$ & $\begin{array}{l}57^{\circ} 2^{\prime} 50.15^{\prime \prime} \\
24^{\circ} 19^{\prime} 42.49^{\prime \prime}\end{array}$ & 0.2 & 198.7 & $10.3 / 4.6$ & throughflow & This study \\
\hline 22 & Lake Lilastes & $\begin{array}{l}57^{\circ} 10^{\prime} 52.30^{\prime \prime} \\
24^{\circ} 21^{\prime} 25.42^{\prime \prime}\end{array}$ & 0.5 & 183.6 & $3.2 / 2$ & throughflow & This study \\
\hline
\end{tabular}


Table 2. Study sites and related information.

\begin{tabular}{|c|c|c|c|c|c|c|c|}
\hline No & Site Name & $\begin{array}{c}\text { Coordinates, } \\
\mathrm{N}, \mathrm{E}\end{array}$ & $\begin{array}{l}\text { Elevation, } \\
\text { m a.s.l. }\end{array}$ & Size, ha & $\begin{array}{l}\text { Water Depth, } \\
\text { max/mean, m }\end{array}$ & $\begin{array}{c}\text { Hydrology, Through- } \\
\text { flow/Inflow/Outflow/None }\end{array}$ & Reference \\
\hline 23 & Lake Āraišu & $\begin{array}{l}57^{\circ} 15^{\prime} 1.02^{\prime \prime} \\
25^{\circ} 17^{\prime} 24.02^{\prime \prime}\end{array}$ & 120.2 & 32.6 & $12.2 / 4$ & throughflow & [14] \\
\hline 24 & Lake Trikātas & $\begin{array}{l}57^{\circ} 32^{\prime} 28.40^{\prime \prime} \\
25^{\circ} 42^{\prime} 52.31^{\prime \prime}\end{array}$ & 50 & 13 & $6.5 / 1.8$ & throughflow & [14] \\
\hline 25 & Lake Bricu & $\begin{array}{l}57^{\circ} 6^{\prime} 55.06^{\prime \prime} \\
25^{\circ} 52^{\prime} 15.45^{\prime \prime}\end{array}$ & 207.3 & 16 & $2.7 / 1.3$ & throughflow & [14] \\
\hline 26 & $\begin{array}{c}\text { Pond } \\
\text { Esplanādes }\end{array}$ & $\begin{array}{l}55^{\circ} 52^{\prime} 18.51^{\prime \prime} \\
26^{\circ} 30^{\prime} 23.69^{\prime \prime}\end{array}$ & 89.4 & 1.5 & $3.2 / 2$ & none & This study \\
\hline 27 & Lake Gubiščes & $\begin{array}{l}55^{\circ} 53^{\prime} 3.92^{\prime \prime} \\
26^{\circ} 33^{\prime} 43.89^{\prime \prime}\end{array}$ & 108 & 18.5 & $2 / 1$ & none & This study \\
\hline 28 & $\begin{array}{l}\text { Lake Mazais } \\
\text { Stropu }\end{array}$ & $\begin{array}{l}55^{\circ} 54^{\prime} 41.96^{\prime \prime} \\
26^{\circ} 35^{\prime} 29.00^{\prime \prime}\end{array}$ & 110.8 & 15.3 & $4.3 / 2.7$ & outflow & This study \\
\hline 29 & $\begin{array}{l}\text { Lake Lielais } \\
\text { Stropu }\end{array}$ & $\begin{array}{l}55^{\circ} 54^{\prime} 41.96^{\prime \prime} \\
26^{\circ} 35^{\prime} 29.00^{\prime \prime}\end{array}$ & 110 & 417.9 & $6.3 / 3.6$ & throughflow & This study \\
\hline 30 & Lake Gluhoje & $\begin{array}{l}55^{\circ} 55^{\prime} 34.64^{\prime \prime} \\
26^{\circ} 57^{\prime} 2.54^{\prime \prime}\end{array}$ & 13.5 & 1.7 & $3.5 / 1.9$ & none & This study \\
\hline 31 & $\begin{array}{l}\text { Lake Lielais } \\
\text { Svētinu }\end{array}$ & $\begin{array}{c}56^{\circ} 45^{\prime} 38.20^{\prime \prime} \\
27^{\circ} 8^{\prime} 57.84^{\prime \prime}\end{array}$ & 96.2 & 18.8 & $5.8 / 2.9$ & throughflow & [14] \\
\hline 32 & Lake Čertoks & $\begin{array}{c}56^{\circ} 5^{\prime} 1.88^{\prime \prime} \\
27^{\circ} 6^{\prime} 59.13^{\prime \prime}\end{array}$ & 159 & 1.9 & $18.3 / 16$ & none & This study \\
\hline 33 & $\begin{array}{c}\text { Lake } \\
\text { Puderovas }\end{array}$ & $\begin{array}{l}56^{\circ} 36^{\prime} 19.19^{\prime \prime} \\
27^{\circ} 13^{\prime} 17.91^{\prime \prime}\end{array}$ & 145.9 & 9.7 & $4.5 / 1.5$ & throughflow & This study \\
\hline 34 & Lake Zosnas & $\begin{array}{l}56^{\circ} 20^{\prime} 3.09^{\prime \prime} \\
27^{\circ} 18^{\prime} 49.65^{\prime \prime}\end{array}$ & 163.5 & 156.5 & $15.4 / 6$ & throughflow & This study \\
\hline 35 & Lake Dagdas & $\begin{array}{l}56^{\circ} 5^{\prime} 13.72^{\prime \prime} \\
27^{\circ} 33^{\prime} 30.01^{\prime \prime}\end{array}$ & 158.1 & 484.1 & $19.2 / 5.2$ & throughflow & This study \\
\hline 36 & Pond Dagdas & $\begin{array}{l}56^{\circ} 6^{\prime} 11.33^{\prime \prime} \\
27^{\circ} 31^{\prime} 19.50^{\prime \prime}\end{array}$ & 162 & 0.33 & $2.4 / 1.2$ & none & This study \\
\hline
\end{tabular}

Altogether 36 natural and human-made waterbodies were selected for the study. Here we define waterbodies using two terms- "lake" and "pond" - where "lake" is naturally formed and "pond" is of anthropogenic origin. While lakes are sized from 1.4 to ha $3715 \mathrm{ha}$, ponds are in the range of $0.33-5.4$ ha (Table 2). We specifically selected not only lakes but also ponds because there are regions with no natural lakes, not to mention that ponds have not been a subject of investigation for pollen in Baltic countries. Lacustrine sedimentary environment is superb for trapping pollen from the surrounding landscape because, under limited oxygen conditions, pollen can preserve for hundreds to thousands of years. Sediment accumulation rate in lakes in Latvia varies but based on published and unpublished data from 12 lakes (e.g., $[15,16]$ ) our estimates reveal an average sedimentation rate of $0.5284 \mathrm{~cm} /$ year (since CE 1950). Therefore, the top-most three $\mathrm{cm}$ can accumulate during the last $\sim-20$ years, thus representing modern pollen data within the catchment.

A combination of a continental (Eurasia) and maritime (Atlantic Ocean) climate is typical for this area, where the east is more continental and the west-more maritime (Figure 1; Table 3). Waterbodies for the particular study were selected to represent all four continentality index zones-weak (15 sites), moderate (seven sites), average (six sites) and strong (eight sites) (Figure 1). 
Table 3. Continentality index characteristics for the territory of Latvia after [17].

\begin{tabular}{|c|c|c|c|c|c|c|c|c|c|}
\hline \multirow[b]{2}{*}{$\begin{array}{l}\text { Continentality } \\
\text { Index }\end{array}$} & \multicolumn{4}{|c|}{ Air Temperature, ${ }^{\circ} \mathrm{C}$} & \multirow{2}{*}{$\begin{array}{l}\text { Maximal } \\
\text { Freezing } \\
\text { of Soil, } \mathrm{cm}\end{array}$} & \multirow{2}{*}{$\begin{array}{c}\text { Snow } \\
\text { Coverage, } \\
\text { Days }\end{array}$} & \multirow{2}{*}{$\begin{array}{c}\text { Maximal } \\
\text { Water Content } \\
\text { in Snow, } \mathbf{m m}\end{array}$} & \multirow[b]{2}{*}{$\begin{array}{l}\text { Elevation, } \\
\text { m a.s.1. }\end{array}$} & \multirow[b]{2}{*}{$\begin{array}{c}\text { Distance } \\
\text { to Sea, km }\end{array}$} \\
\hline & January & Annual & $\begin{array}{l}\text { Absolute } \\
\text { Minimum }\end{array}$ & $\begin{array}{c}\text { Annual } \\
\text { Minimum }\end{array}$ & & & & & \\
\hline Weak & -3.7 & 5.8 & -33.6 & -22.2 & 38.4 & 87 & 39 & 32 & 13 \\
\hline Moderate & -5.2 & 5.5 & -35.5 & -25.5 & 44.8 & 97 & 49 & 54 & 46 \\
\hline Average & -6.6 & 5.1 & -39.6 & -27.8 & 53.7 & 114 & 71 & 98 & 109 \\
\hline Strong & -7.4 & 4.9 & -40.5 & -29.2 & 57.8 & 123 & 89 & 154 & 186 \\
\hline
\end{tabular}

The average annual air temperature in Latvia is $+6.8^{\circ} \mathrm{C}$ (varied from 5.7 to $8.0^{\circ} \mathrm{C}$ ) for the climatic normal 1991-2020. The lowest mean monthly air temperature observed in February, where it reaches $-3.1^{\circ} \mathrm{C}$ (varied from $-1.1{ }^{\circ} \mathrm{C}$ to $-5.1{ }^{\circ} \mathrm{C}$ ), while the highest mean monthly air temperature $17.8^{\circ} \mathrm{C}$ in July (varied from 17.0 to $19.4^{\circ} \mathrm{C}$ ). The annual precipitation in average reaches $679 \mathrm{~mm}$ (varied from $585 \mathrm{~mm}$ to $885 \mathrm{~mm}$ ) according to the Latvian Environment, Geology and Meteorology Centre data. The highest precipitation amount fell during the summer months (July and August) and in autumn, while the driest periods were in winter and early spring.

\subsection{Sediment Sampling}

The top-most $3 \mathrm{~cm}$ sediment sample from waterbodies was obtained using a gravitycorer (๑ KC Denmark) through ice in winter 2021 and from a boat in winter 2020 and spring 2021. Samples were taken at the deepest place of the middle of the waterbodies. Surface sediment samples were subsampled at the field, put in small plastic bags, transported to the University of Latvia, and stored at $4-6{ }^{\circ} \mathrm{C}$.

\subsection{Pollen Analysis}

Pollen subsamples of known volume $\left(1 \mathrm{~cm}^{3}\right)$ were treated with $10 \% \mathrm{HCl}$, boiled in $10 \% \mathrm{KOH}$, and then acetolyzed for $3 \mathrm{~min}$ using standard acetolysis procedure [18]. Prior to chemical treatment, Lycopodium spores containing tablets were added to sediment samples in order to estimate the concentration of pollen per $\mathrm{cm}^{3}$ [19]. The prepared samples were stored in glycerine. A minimum of 500 terrestrial pollen was counted from each slide. Pollen identification was carried out to the lowest possible taxonomic level, with the help of the identification guide of [20] and a modern pollen reference collection stored at the University of Latvia and Tallinn University of Technology. Additional pollen data were obtained from $[14,15]$ (Table 2). Results from these publications are comparable because pollen analyses for these sites and publications were done by Normunds Stivrins with the same preparation and identification procedure. The percentage of dry-land taxa was calculated using arboreal (AP) and non-arboreal (NAP) pollen sums (excluding sporomorphs of aquatic and wetland plants). Counts of spores were calculated as percentages of the total sum of terrestrial pollen. The pollen diagram was compiled using TILIA software [21]. Pollen accumulation rate (PAR) was estimated by multiplying pollen concentration per sample with mean sediment accumulation rate in Latvian lakes $(0.5284 \mathrm{~cm} /$ year).

\subsection{Climate and Landscape}

Climate data for each pollen surface sample site were derived from the nearest meteorological station. Time series of air temperature and precipitation were collected from the Latvian Environment, Geology and Meteorology Centre and represent reference period of climate normal for 1991-2020. For each sampling site, long-term observations of the nearest meteorological station were used to calculate the average annual air temperature, the average temperature in winter and summer seasons and the amount of annual precipitation, as well for winter and summer seasons.

According to study [17], the main climatic factors that reflect the degree of climate continentality and its increasing eastward sea distance in Latvia are minimum winter air temperature, duration of snow cover, depth of soil freezing. Based on these climatic indicators, they determined four continentality indices that have been used in the particular study. 
We characterized land cover using Corine Land Cover 2018 data [22] with aggregated thematic land cover categories (forests, agricultural areas, urban areas). We estimated forest biomass in $1 \mathrm{~km}$ and $4 \mathrm{~km}$ buffer zones around waterbodies from State Forest Register database [23] by summarizing standing timber volume from all forest compartments inside buffer zones. We used the Geological Map of Latvia [24] to characterize quaternary sediments in buffer zones.

Buffer zones were set to test how reliable pollen reflecting the surrounding setting is. There are various options and publications related to this topic, but following [4] we selected two buffer zones- $-1 \mathrm{~km}$ and $4 \mathrm{~km}$. We measured buffer zone from the margin of the lake following the shape of the waterbody as suggested by [25]. Although it would be enough with one buffer zone, to test how reliable pollen can be used in tree biomass reconstructions (see [4]), we estimated modern tree biomass around the sites in 1 and $4 \mathrm{~km}$ buffer (calibration) zones. Therefore, all other landscape characteristics were set at the same zonation parameters.

\subsection{Data Analyses}

Statistical correlation of analyzed pollen, sites and variables was tested by using principal components analysis (PCA), which finds components accounting for as much as possible of the variance in data [26,27]. Significance of components was tested using broken stick method [28]. PCA was done in Past v.4.05 [29].

Cross-correlations between pollen results and CORINE landcover (forests, agricultural and urban area; \%) data, as well as PAR and tree biomass $\left(\mathrm{m}^{3}\right)$ around lakes in $1 \mathrm{~km}$ and $4 \mathrm{~km}$ radius were calculated with Pearson correlation tests using cor.test() function in $\mathrm{R}$ (version 4.0.5.; [30]). Pearson's correlation was conducted under the assumption that there is a linear relationship between pollen composition and the actual data. Lake sizes were taken into account under the assumption that their size may have an indirect influence on the sediment pollen composition, thus also the closeness of the relationship between two variables. Study sites were divided into three groups: all, large ( $>50 \mathrm{ha}$ ) and small-medium lakes ( $<50 \mathrm{ha})$. Correlations were performed to determine whether modern pollen data can be quantified and validated based on current vegetation and tree biomass estimates, thus contributing to the reconstruction of long-term boreonemoral vegetation and biomass characteristics in the northeastern Europe region based on sub-fossil pollen data acquired from waterbodies of different sizes. Due to non-homogenous site sizes and specific soil types such alternative method as REVEALS modelling was not conducted.

\section{Results}

\subsection{Climate}

Analyzed sites fall in non-linear distribution when considering climate parameters, but certain links can be drawn. Coastal (oceanic) sites have higher average temperatures and precipitations (Figure 2), while lower average temperatures and precipitations are characteristic of inland (continental) sites. There are also differences in the distribution of summer and winter temperatures - the lowest summer and highest winter temperatures are typical of sites near the open Baltic Sea coast, because of the large thermal inertia of the sea and to the flow of mild maritime air from the west. For sites with average and strong continentality and higher elevations, the winter temperatures are considerably lower. The same factors affect the distribution of seasonal precipitation-the higher summer precipitation is characterized for inland sites while lower for coastal locations. 

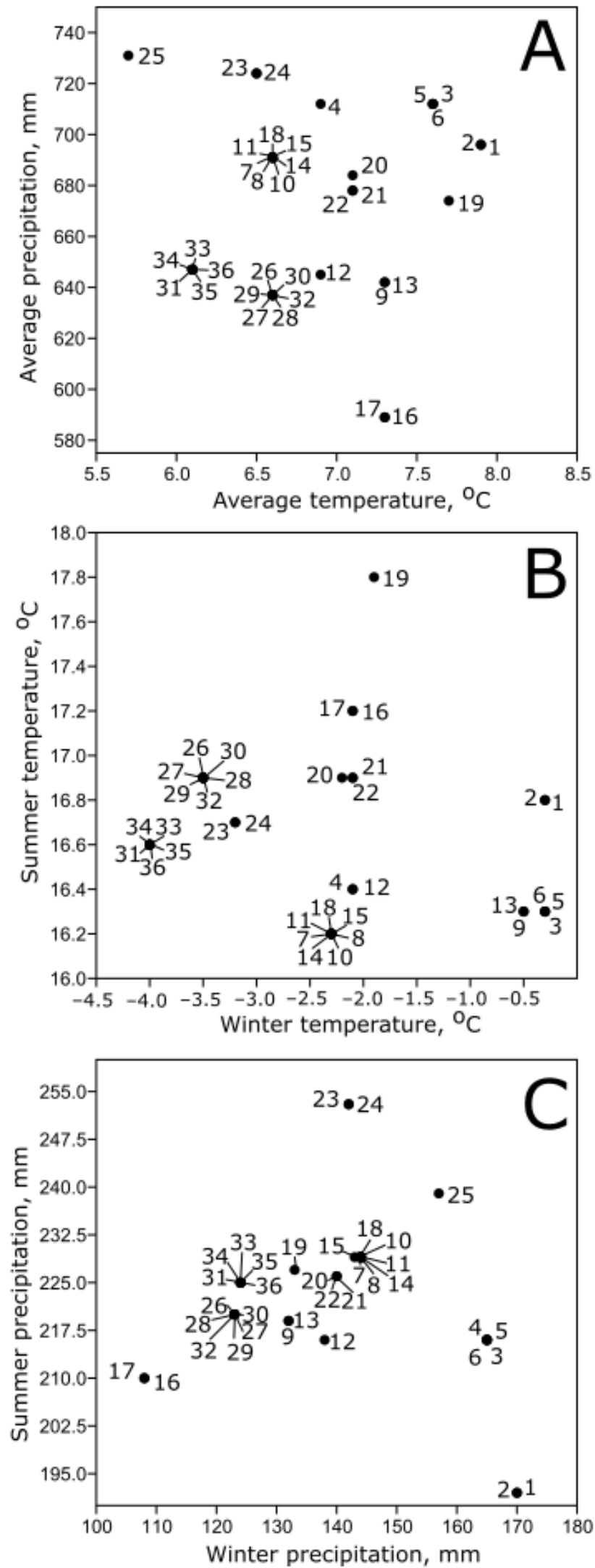

Figure 2. Scatterplots showing (A) average precipitations ( $\mathrm{mm}$ ) versus average temperatures (C), (B) summer versus winter temperature (C) and (C) summer versus winter precipitation ( $\mathrm{mm}$ ) for the 36 sites (site names and location within the Latvia see Table 2 and Figure 1). 


\subsection{Quaternary Sediment and Soil}

The majority of sites are dominated by glacigenic and glaciolacustrine Quaternary sediment (Figure 3). Glacigenic sediment consists of till—unsorted clay, clay-gravel material deposited directly by glacial ice. Meanwhile, glaciolacustrine sediment genesis involves formation in lakes deposited by glacial meltwater. Only one waterbody is located in the eolian sand and alluvial sand region. Quaternary sediment in large part forms a ground for topsoil where on glacigenic sediment are dystric cambisol (E1Pv) and stagnosols/planosols (Pgv), and on glaciolacustrine sediment dominate luvisols/alisols (Pv) (Figure 3).

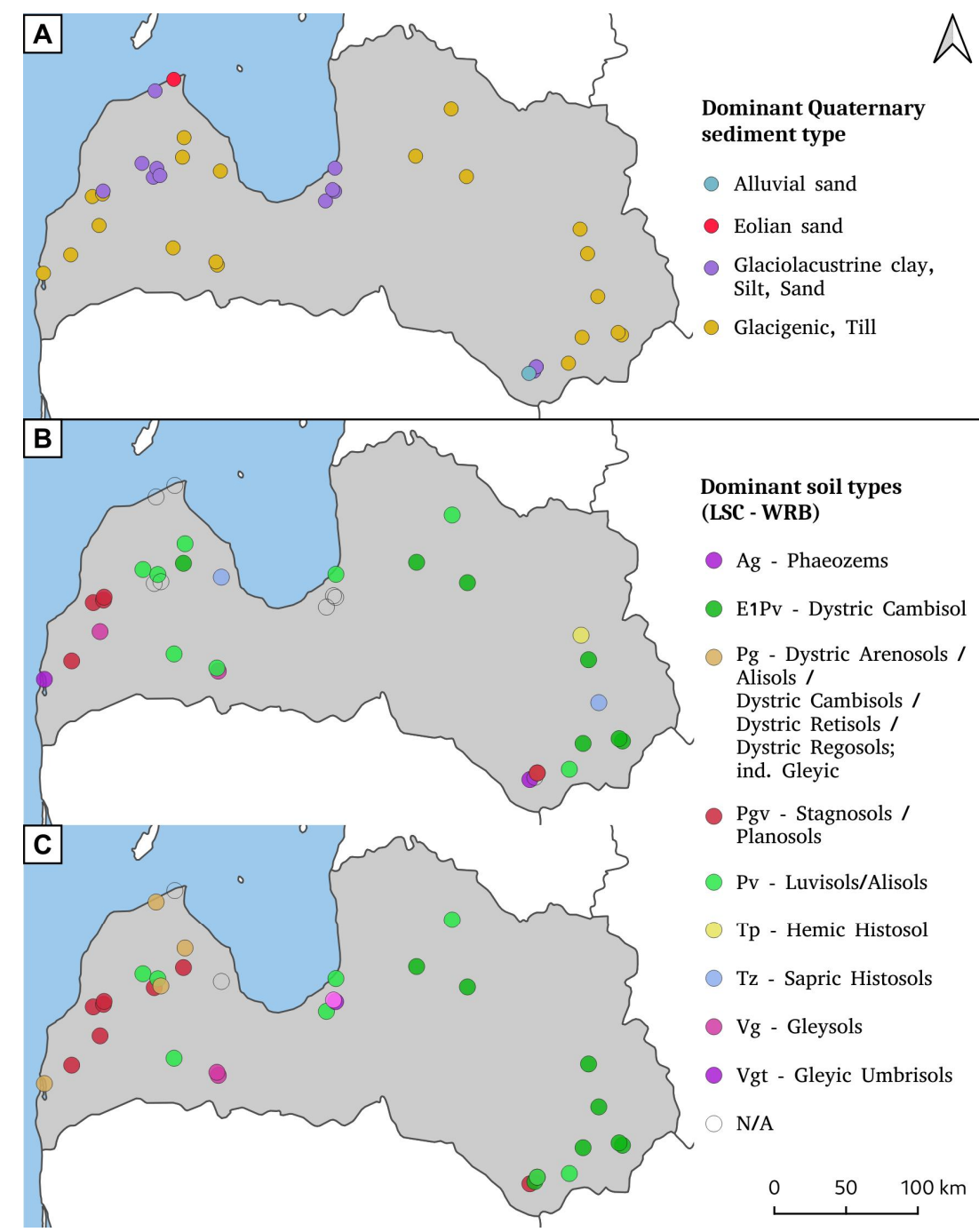

Figure 3. Dominant Quaternary sediment type within $4 \mathrm{~km}$ around the waterbodies (A) and dominant soil (LSC-WRB) type within $1 \mathrm{~km} \mathrm{(B)} \mathrm{and} 4 \mathrm{~km} \mathrm{(C).} \mathrm{LSC-Latvian} \mathrm{Soil} \mathrm{Classification} \mathrm{and} \mathrm{WRB-}$ World Reference Base for Soil Resources.

\subsection{Pollen}

Altogether 81 pollen taxa were identified from 36 sites (Figure 4; Supplementary Material). Dominant tree taxa in the majority of sites were Pinus, Betula, Picea, Alnus, and Corylus. Higher Pinus values were recorded at lower altitudes, while higher Betula relative share was identified from sites at higher altitude sites. 


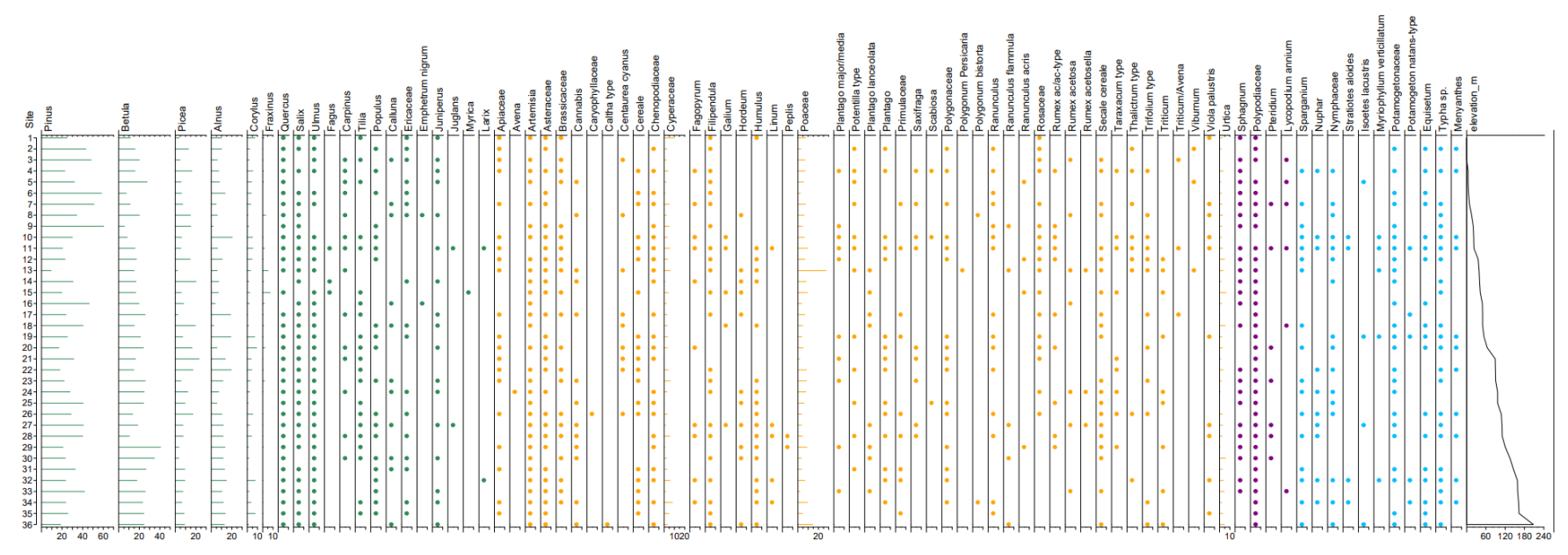

Figure 4. Pollen percentages diagram showing all pollen and spores identified from 36 lake and pond samples alongside altitudinal gradient. Values on horizontal axes are percentages. Shading in gray is an exaggeration at $\times 10$ for pollen data to ease visibility of low percentage values of taxa particularly. Site names for appropriate number see Figure 1 and Table 2.

Pollen records of plants related to human activities and influence on the vegetation composition throughout the altitudinal gradient are variable. As ruderal species tend to be characteristic of disturbed environments, most often affected by human activities, the increase in their abundance in the surface sediments of the lake is expected in relation to the wider open landscape area around the waterbody. It can also be caused by the urban environment and the use of adjacent areas for agriculture. In this study, more than 25 different species of cultivated land and ruderal plant species or genera were found in surface sediments. Chenopodiaceae, Artemisia and Urtica predominate among the pollen of ruderal plants. Cultivated land plant pollen has been found in low numbers, predominantly Hordeum, Triticum and Brassicaceae pollen in waterbodies located near agricultural lands. An increased amount of pollen from grasses and sedges can also be considered as an effect of human activity, indicating the intensity of the overgrowth of the lake. This evidence is more characteristic for sites with throughflow hydrological regime collecting pollen from the wider catchment areas, for instance, Lake Kikuru, Lake Durbes, Lake Liepājas, Lake Sesavas (Table 2; Figure 4). The composition of pollen in man-made reservoirs (ponds) is quite different, which is probably related to their management measures.

The broken stick method indicated four main principal components (PC) strongly weighted by Pinus (PC1), Betula (PC2), Picea (PC3) and Alnus (PC4) (Figure 5A). Although insignificant, it is worth underlining also PC5-Poaceae, human-related cultivated and ruderal plants. Results of PCA show sites in glaciolacustrine (clay, silt, and sand) areas are mostly forested, while sites in glacigenic (till) sediments display the opposite situationopen landscape and human-related agricultural pollen and vegetation (Figure 5B). 


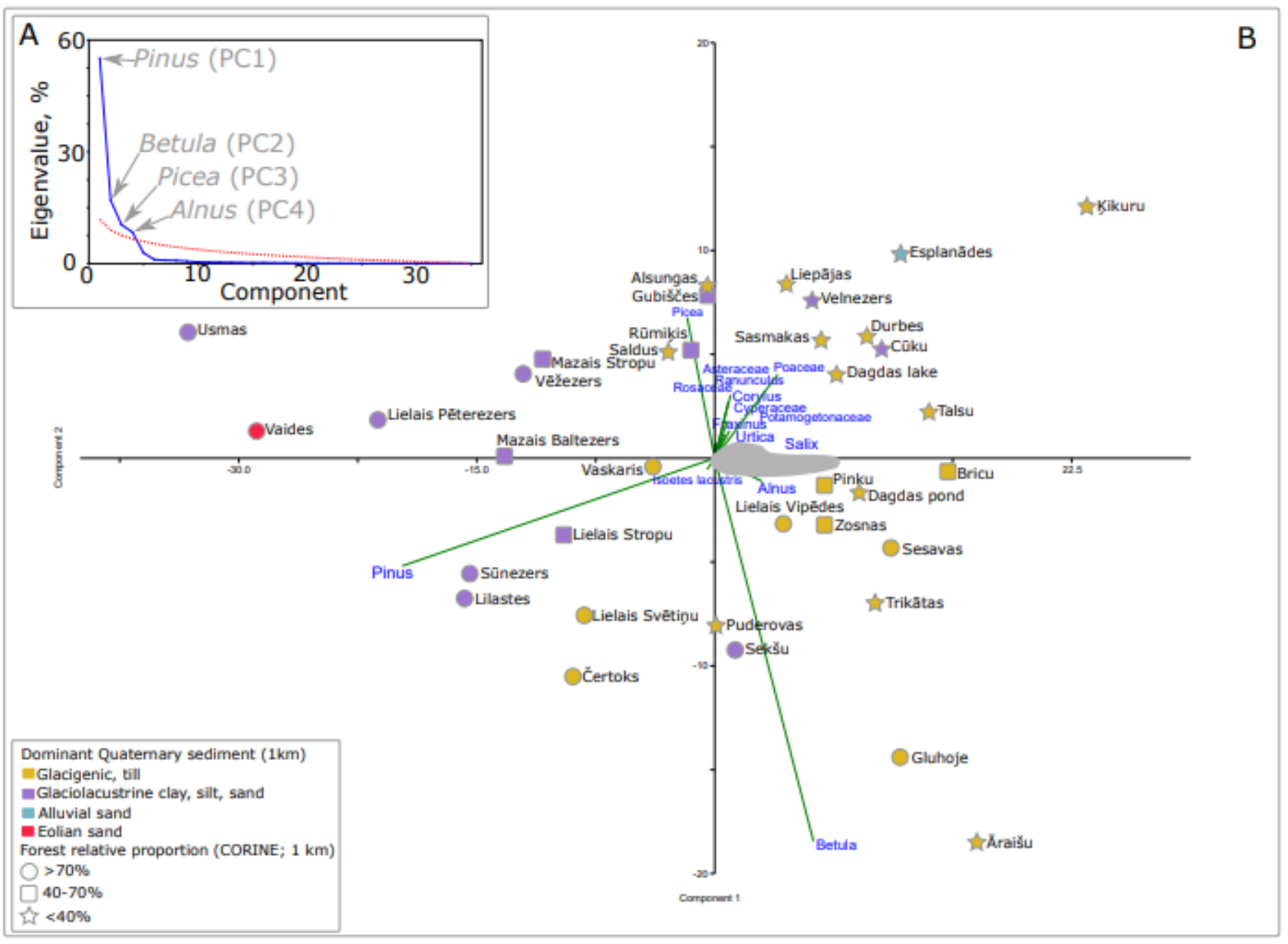

Figure 5. Principal component analyses of modern pollen in waterbodies with (A) Eigenvalues of first four significant principal components and the strongest associations, and (B) over all pollen dispersal and distribution between sites indicating both dominant Quaternary sediment and the relative forest share (CORINE) within $1 \mathrm{~km}$ radius around the waterbodies. Gray elongated area shows the location of pollen taxa that were indistinguishable and do not have a strong influence on the first axes.

Results obtained in our study show a positive linear correlation between the actual forest cover around the sites (CORINE data) and tree pollen in surface sediment samples reflecting forest relative share (\%) in the landscape. Obtained results reveal that if all studied sites are included, forest cover (1 km buffer zone) and tree pollen (\%) correlation reached r: 0.39 (Figure 6A). Lower correlation ( $\mathrm{r}$ : 0.30) was for $4 \mathrm{~km}$ buffer zone. The highest correlation up to $\mathrm{r}$ : 0.86 (4 km buffer zone) and r: 0.87 ( $1 \mathrm{~km}$ buffer zone) was obtained when including only large sites (Figure 6B). Tree biomass and tree PAR had r: 0.33 correlation for sites smaller than 50 ha (Figure 6C) and only r: 0.1 when all sites considered (Figure 6D). A slightly higher correlation was for agricultural land (\%, CORINE) and agricultural pollen (cultivated plants, \%) where r: 0.42 was reached when including all sites. Negative r: -0.27 correlation was between urban area (\%,CORINE) and agricultural pollen (\%). It is worth mentioning that only the highest correlations are shown in Figure 6. 

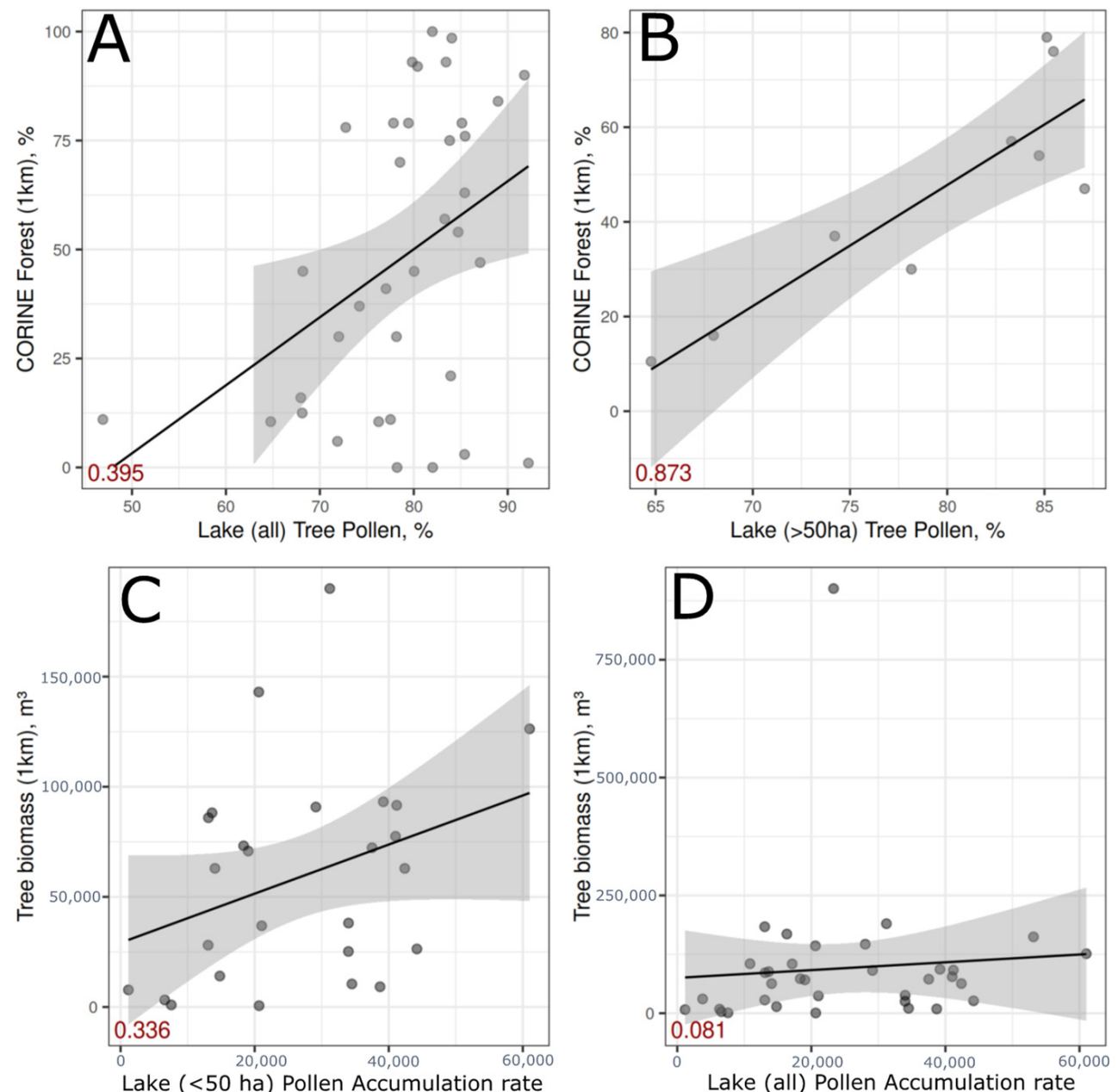

Lake ( $<50$ ha) Pollen Accumulation rate

Lake (all) Pollen Accumulation rate
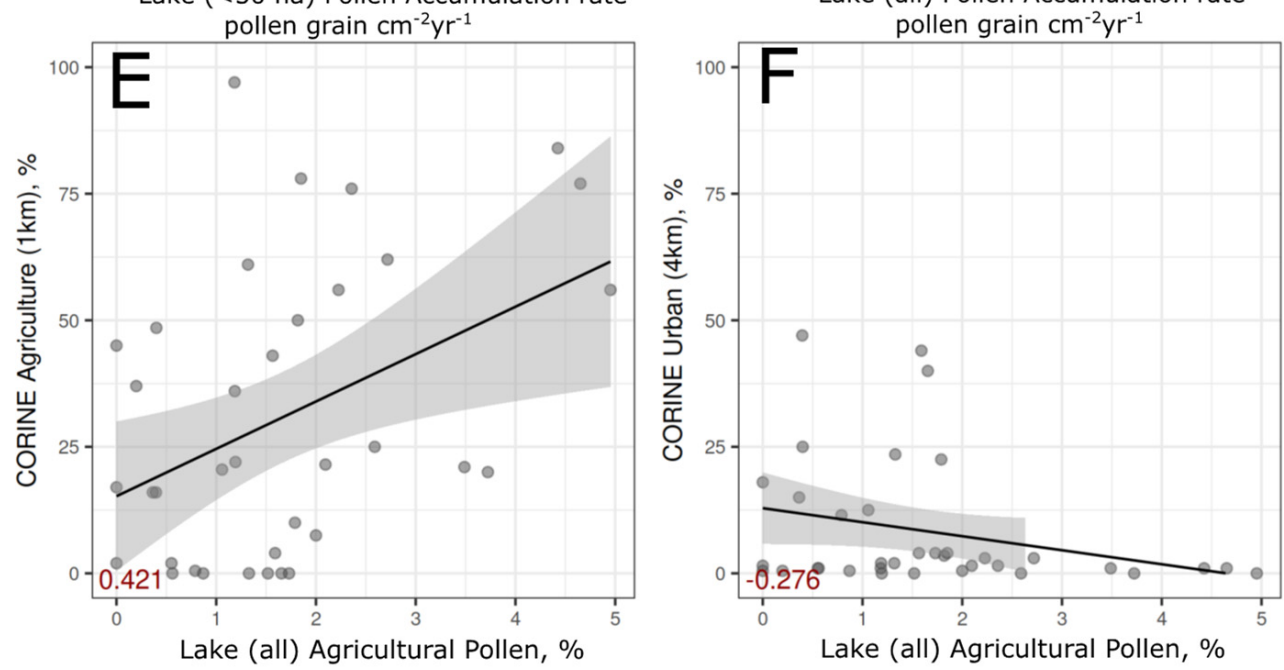

Figure 6. Pearson correlation of (A) relative share of forest (\%, CORINE based estimates) within $1 \mathrm{~km}$ around the waterbodies and tree pollen (\%) from all study sites, (B) relative share of forest (CORINE based estimates) within $1 \mathrm{~km}$ around the large lakes and tree pollen (\%) from large lakes (>50 ha), (C) tree biomass $\left(\mathrm{m}^{3}\right)$ within $1 \mathrm{~km}$ around the large lakes and tree pollen concentration (pollen grains per sample) from large lakes ( $>50 \mathrm{ha}$ ), (D) tree biomass $\left(\mathrm{m}^{3}\right)$ within $4 \mathrm{~km}$ around all waterbodies and tree pollen concentration (pollen grains per sample) from all sites, (E) agricultural fields (\%) within $1 \mathrm{~km}$ around all waterbodies and agricultural (cultivated vegetation) pollen (\%) from all sites and (F) urban area (\%) within $4 \mathrm{~km}$ and agricultural (cultivated vegetation) pollen (\%) from all sites. Gray shading represents $95 \%$ confidence level. 


\section{Discussion}

Higher pine and spruce pollen dominance was found in sites located at lower altitudes (Figure 4). When looking within sites, pine has a close connection to glaciolacustrine and eolian sediment distribution where nearly all sites forest coverage is $>40 \%$ as is reflected by the results of PCA (Figure 5). The opposite situation is in sites dominated by herbs and cultivated plants where forest cover is $<40 \%$ and the dominant Quaternary sediment is glacigenic till. While commonly modern pollen is displayed alongside altitudinal or temperature gradient [31], we found it was not meaningful in such low elevations as in Latvia. Instead, Quaternary sediment and subsequent soil type has the main controlling factor for vegetation distribution and patterns. Historically, areas dominated by glaciolacustrine, glaciofluvial, marine, and eolian Quaternary sediment form acidic sandy podsol soils are poor in nutrients and thus unattractive for farming.

Pine, spruce and birch are among the most common and also economically valuable tree species. Today pine (Pinus sylvestris) is making $40 \%$, spruce (Picea abies) $22 \%$ and birch (Betula pubescens, Betula pendula) $36 \%$ of all tree species in Latvia [32]. Considering the high value of ecosystem services, it is crucial to clarify, for instance, how the forest biomass of the main tree species has changed. This can be found out by using pollen-based tree biomass reconstructions [4]. Before proceeding with any reconstruction, pollen accumulation rate data need to be calibrated to modern tree biomass values. Here we provide the first modern pollen calibration to the modern tree biomass values for Latvia and in this study obtained results show relatively low correlations (r: 0.18 to r: 0.33) (Figure 6C,D). Possible reason for such low correlation outcome can be site selection. In their seminal paper about the biomass reconstructions, Seppä et al. [4] indicated—only small-medium sized lakes characterized by predominantly constant long-term sedimentation rates and relatively floristically simple composition are the most suitable sites for tree biomass reconstructions. Our results show a higher correlation for sites ( $\mathrm{r}$ : 0.33) where small to medium-sized waterbodies predominated. From the obtained results is possible to draw several steps that can be considered in the tree biomass reconstructions. As results show, not all sites can be used appropriately and therefore only selected sites must be included in the forest biomass-training set.

Our results show that modern pollen assemblages from waterbody surface sediments reflect the actual landscape characteristics and overall vegetation coverage. A fairly good correlation ( $\mathrm{r}: 0.87$ ) between forest coverage and tree pollen percentages from large ( $>50 \mathrm{ha}$ ) lakes (Figure 6B) were found. Based on this, we consider that pollen from large sites (>50 ha) better reflect the relative forest cover. Surprisingly, obtained results show a lower correlation between forest cover and tree pollen from small-medium sized waterbodies. A possible explanation for this finding can be a larger portion of regional pollen. Models and observations based on empirical investigations confirm that small lakes have smaller pollen source areas than large lakes [33,34]. The Prentice-Sugita pollen dispersal and deposition model predicts that within the same landscape pollen percentages are highly variable in small ponds but uniform in larger lakes (lakes with diameter $>250 \mathrm{~m}$ ) [1,35]. Considering that the relative source area of pollen of lakes within a radius up to $100 \mathrm{~m}$ has been shown to be $<2000 \mathrm{~m}$ from the center of the lakes [36], our small-medium sized waterbodies (radius 20-200 m), theoretically, should show pollen spectrum within 1 to $4 \mathrm{~km}$. Differences in buffer zones and correlation outcome suggesting more work should be done for calibration purposes in hemiboreal zone.

Human impact on the landscape and subsequently on vegetation is evident through the modern pollen data. For instance, we found that when the urban area around the waterbody is more common, the relative share of agricultural pollen is lower (Figure 6F). Although this correlation was weak and even negative ( $\mathrm{r}$ : -0.27$)$, it still underlines the general trend of such correlation. When we consider waterbodies located within agricultural areas, the correlation between agricultural pollen was significantly higher $\mathrm{r}: 0.42$ (Figure 6E). A lower correlation than expected can be linked to various land management aspects. Theuerkauf et al. [37] studied the effects of changes in land management practices 
on pollen productivity in Germany and found that decline in herb and grass pollen since the 1950s occurred not only due to a shift towards crops that emit comparatively small number of pollen but also earlier and more frequent mowing of grasses.

Modern pollen data are highly valuable in climate reconstructions and modeling. For instance, the most common climate reconstructions are sub-fossil pollen-based approaches which are using modern pollen training sets for calibration purposes [14,38]. As Seppä et al. [31] noted, due to human impact on the landscape, not all sites can be used for pollen-training set purposes. For instance, small-medium sized waterbodies (20-50 ha), with no significant human impact (e.g., large fields, forest management, housing areas) in the vicinity, $>1.5 \mathrm{~m}$ deep, dominated by glacigenic and glaciolacustrine sediment [38] are more suitable for pollen-climate calibration sets. According to these requirements, only seven waterbodies (Lake Bricu, Lake Čertoks, Lake Lielais Svētinu, Lake Lielais Vipēdis, Lake Pinku, Lake Sesavas and Lake Gluhoje) from this study could be selected for climate reconstructions, although selection also depends on the chosen technique. Fortunately, the methodology of climate reconstruction techniques is advancing and most of these results and sites can be applicable for the reconstructions $[8,38]$.

\section{Conclusions}

(1) Large waterbodies reflect forest cover better than small-medium-sized waterbodies.

(2) Pollen accumulation rate can be used for forest biomass reconstructions after additional site selection and calibration work.

(3) Agricultural pollen percentages decrease with the increasing urban area around the waterbody.

(4) Modern pollen from surface samples in waterbodies represent current forest and human land use.

(5) Quaternary sediment and subsequent soil type have the main controlling factor for vegetation distribution patterns.

(6) More fertile soils in regions dominated by glacigenic Quaternary sediment show distinct human impact through increased agricultural activities and open landscape.

Supplementary Materials: The following are available online at https:/ /www.mdpi.com/article/ 10.3390/f12091166/s1, Pollen raw counts S1 Excel file.

Author Contributions: Conceptualization, N.S.; methodology, N.S., L.K., Z.R., A.B.; software; validation; formal analysis, N.S., L.K., A.B., Z.R., J.J.; investigation, N.S., A.M., D.S., L.T., N.J., J.J.; writing—original draft preparation, N.S., L.K., A.B., Z.R., J.J., L.T., D.S.; writing—review and editing, N.S., L.K., Z.R., A.B., L.T., D.S.; visualization, N.S., D.S., A.B., Z.R., J.J.; supervision; project administration, N.S.; funding acquisition, N.S.; All authors have read and agreed to the published version of the manuscript.

Funding: Research was funded by the Latvian Council of Science project No. LZP-2020/2-0060 “Establishing training data set of pollen and non-pollen palynomorphs for Latvia-fundamental ground for climate, landscape, vegetation and water quality reconstructions and modelling", performancebased National basic funding for science of the University of Latvia within the "Climate change and sustainable use of natural resources" (Y5-AZ03_ZF-N-110) program, and the Estonian Council of Research ETF 9031 and IUT 1-8.

Data Availability Statement: Data are available for free alongside this article (see Supplementary Material).

Conflicts of Interest: The authors declare no conflict of interest.

\section{References}

1. Sugita, S. Pollen representation of vegetation in Quaternary sediments: Theory and method in patchy vegetation. J. Ecol. 1994, 82, 881-897. [CrossRef]

2. Sugita, S. Theory of quantitative reconstruction of vegetation. I. Pollen from large sites REVEALS regional vegetation composition. Holocene 2007, 17, 229-241. [CrossRef] 
3. Lisitsyna, O.; Hicks, S.; Huusko, A. Do moss samples, pollen traps and modern lake sediments all collect pollen in the same way? A comparison from the forest limit area of northernmost Europe. Veget. Hist. Archaeobot. 2012, 21, 187-199. [CrossRef]

4. Seppä, H.; Alenius, T.; Muukkonen, P.; Giesecke, T.; Miller, P.A.; Ojala, A.E.K. Calibrated pollen accumulation rates as a basis for quantitative tree biomass reconstructions. Holocene 2009, 19, 209-220. [CrossRef]

5. Maguire, K.C.; Nieto-Lugilde, D.; Firzpatrick, M.C.; Williams, J.W.; Blois, J.L. Modeling species and community responses to past, present, and future episodes of climatic and ecological change. Annu. Rev. Ecol. Evol. Syst. 2015, 46, 343-368. [CrossRef]

6. Reitalu, T.; Gerhold, P.; Poska, A.; Pärtel, M.; Väli, V.; Veski, S. Novel insights into post-glacial vegetation change: Functional and phylogenetic diversity in pollen records. J. Veg. Sci. 2015, 26, 911-922. [CrossRef]

7. Carvalho, F.; Brown, K.A.; Waller, M.P.; Bunting, M.J.; Boom, A.; Leng, M.J. A method for reconstructing temporal changes in vegetation functional trait composition using Holocene pollen assemblages. PLoS ONE 2019, 14, 1-18. [CrossRef]

8. Salonen, J.S.; Korpela, M.; Williams, J.W.; Luoto, M. Machine-learning based reconstructions of primary and secondary climate variables from North American and European fossil pollen data. Sci. Rep. 2019, 9, 1-13. [CrossRef] [PubMed]

9. Tierney, J.E.; Zhu, J.; King, K.; Malevich, S.B.; Hakim, G.J.; Poulsen, C.J. Glacial cooling and climate sensitivity revisited. Nature 2020, 584, 569-573. [CrossRef]

10. Breitenbach, S.F.M.; Rehfeld, K.; Goswami, B.; Baldini, J.U.L.; Ridley, H.E.; Kennett, D.J.; Prufer, K.M.; Aquino, V.V.; Asmerom, Y.; Polyak, V.J.; et al. Constructing proxy records from age models (COPRA). Clim. Past 2012, 8, 1765-1779. [CrossRef]

11. Luoto, T.P.; Ojala, A.E.K.; Arppe, L.; Brooks, S.J.; Kurki, E.; Oksman, M.; Wooller, M.J.; Zajaczkowski, M. Synchronized proxybased temperature reconstructions reveal mid- to late Holocene climate oscillations in High Arctic Svalbard. J. Quat. Sci. 2018, 33, 93-99. [CrossRef]

12. Reschke, M.; Kröner, I.; Laepple, T. Testing the consistency of Holocene and Last Glacial Maximum spatial correlations in temperature proxy records. J. Quat. Sci. 2021, 36, 20-28. [CrossRef]

13. IPCC. Climate Change 2014: Synthesis Report. In Core Writing Team, Contribution of Working Groups I, II and III to the Fifth Assessment Report of the Intergovernmental Panel on Climate Change; Pachauri, R.K., Meyer, L.A., Eds.; IPCC: Geneva, Switzerland, 2014; p. 151.

14. Davis, B.A.S.; Chevalier, M.; Sommer, P.; Carter, V.A.; Finsinger, W.; Mauri, A.; Phelps, L.N.; Zanon, M.; Abegglen, R.; Ákesson, C.M.; et al. The Eurasian Modern Pollen Database (EMPD), Version 2. Earth Syst. Sci. Data 2020, 12, 2423-2445. [CrossRef]

15. Zawiska, I.; Dimante-Deimantovica, I.; Luoto, T.P.; Rzodkiewicz, M.; Saarni, S.; Stivrins, N.; Tylmann, W.; Lanka, A.; Robeznieks, M.; Jilbert, T. Long-term consequences of water punping on the ecosystem functioning of Lake Sekšu, Latvia. Water 2020, 12, 1459. [CrossRef]

16. Stivrins, N.; Grudzinska, I.; Elmi, K.; Heinsalu, A.; Veski, S. Determining reference conditions of hemiboreal lakes in Latvia, NE Europe: A palaeolimnological approach. Ann. Limnol. Int. J. Limnol. 2018, 54, 1-22. [CrossRef]

17. Laiviňš, M.; Melecis, V. Bio-geographical interpretation of climate data in Latvia: Multidimensional analysis. Acta Uni. Latv. 2003, $654,7-22$.

18. Berglund, B.E.; Ralska-Jasiewiczowa, M. Pollen analysis and pollen diagrams. In Handbook of Holocene Palaeoecology and Palaeohydrology; Berglund, B.E., Ed.; Wiley: Chichester, UK, 1986; pp. 455-484.

19. Stockmarr, J. Tablets with spores used in absolute pollen analysis. Pollen Spore 1971, 13, 615-621.

20. Moore, P.D.; Webb, J.A.; Collinson, M.E. Pollen Analysis; Blackwell Scientific Publications: Oxford, UK, 1991 ; p. 216.

21. Grimm, E.C. Tilia Software for Palynologists. 2021. Available online: www.tiliait.com (accessed on 14 June 2019).

22. European Environmental Agency. Corine Land Cover Data; European Union, Copernicus Land Monitoring Service: 2020. Available online: https:/ / land.copernicus.eu/pan-european/corine-land-cover/clc2018 (accessed on 20 April 2021).

23. State Forest Service. State Forest Register Database; State Forest Service: Riga, Latvia, 2019. Available online: https://latvija.lv/en/ PPK/uznemejdarbiba/registri/p6431/ProcesaApraksts (accessed on 5 July 2020).

24. Geological Map of Latvia. Quaternary Deposits; Scale 1:200,000; State Geological Survey: Riga, Latvia, 1997.

25. Matthias, I.; Giesecke, T. Insights into pollen source area, transport and deposition from modern pollen accumulation rates in lake sediments. Quat. Sci. Rev. 2014, 87, 12-23. [CrossRef]

26. Davis, J.C. Statistics and Data Analysis in Geology; John Wiley and Sons: Hoboken, NJ, USA, 1986; p. 140.

27. Legendre, P.; Legendre, L. Numerical Ecology, 2nd ed.; Elsevier: Amsterdam, The Netherlands, 1998 ; p. 853.

28. Jackson, D.A. Stopping rules in principal components analysis: A comparison of heuristical and statistical approaches. Ecology 1993, 74, 2204-2214. [CrossRef]

29. Hammer, Ø.; Harper, D.A.T.; Ryan, P.D. PAST: Paleontological statistics software package for education and data analysis. Palaeontol. Electron. 2001, 4, 9.

30. R Core Team. R: A Language and Environment for Statistical Computing; R Foundation for Statistical Computing: Vienna, Austria, 2021; Available online: https:/ / www.R-project.org/ (accessed on 22 February 2021).

31. Seppä, H.; Birks, H.J.B.; Odland, A.; Poska, A.; Veski, S. A modern pollen-climate calibration set from northern Europe: Developing and testing a tool for palaeoclimatological reconstructions. J. Biogeogr. 2004, 31, 251-267. [CrossRef]

32. Forest Statistics in Latvia. Meža Statistikas CD (vmd.gov.lv). 2018. Available online: https://www.vmd.gov.lv/valsts-mezadienests / statiskas-lapas / publikacijas-un-parskati/meza-statistikas-cd?nid=1809\#jump (accessed on 4 April 2021). 
33. Poska, A.; Saarse, L.; Koppel, K.; Nielsen, A.B.; Avel, E.; Vassiljev, J.; Vali, V. The Varijärv area, South Estonia over the last millennium: A high resolution quantitative land-cover reconstruction based on pollen and historical data. Rev. Palaeobot. Palynol. 2014, 207, 5-17. [CrossRef]

34. Sugita, S. Theory of quantitative reconstruction of vegetation. II. All you need is LOVE. Holocene 2007, 17, 243-257. [CrossRef]

35. Prentice, I.C. Records of vegetation in time and space: The principles of pollen analysis. In Vegetation History; Huntley, B., Webb, T., Eds.; Kluwer Academic Publishers: Dordrecht, The Netherlands, 1988; pp. 17-42.

36. Poska, A.; Meltsov, V.; Sugita, S.; Vassiljev, J. Relative pollen productivity estimates of major anemophilous taxa and relevant source area of pollen in a cultural landscape of the hemi-boreal forest zone (Estonia). Rev. Palaeobot. Palynol. 2011, 167, 30-39. [CrossRef]

37. Theuerkauf, M.; Drager, N.; Kienel, U.; Kuparinen, A.; Brauer, A. Effects of changes in land management practices on pollen productivity of open vegetation during the last century derived from varved lake sediments. Holocene 2015, 25, 733-744. [CrossRef]

38. Chevalier, M.; Davis, A.S.; Heiri, O.; Seppä, H.; Chase, B.M.; Gajewski, K.; Lacourse, T.; Telford, R.J.; Finsinger, W.; Guiot, J.; et al. Pollen-based climate reconstruction techniques for late Quaternary studies. Earth-Sci. Rev. 2020, 210, 103384. [CrossRef] 